\title{
ANTICOAGULANT RESISTANCE IN SYNANTHROPIC RODENTS IN THE STARA ZAGORA REGION, BULGARIA
}

\author{
Georgi G. Zhelev ${ }^{1}$ Kojcho P. Koev¹, Vladimir D. Dimitrov², Vladimir S. Petrov ${ }^{1}$ \\ ${ }^{1}$ Department of Epidemiology, Infectious Diseases and Preventive Medicine, Faculty of \\ Veterinary Medicine, Trakian University, Stara Zagora 6000, Bulgaria \\ ${ }^{2}$ Veterinarian, Varna 9000, Bulgaria
}

Received 2 March 2018; Received in revised form 26 November 2018; Accepted 29 November 2018

\begin{abstract}
The anticoagulant rodenticides are the most commonly used toxicants to control rodents nowadays. Therefore, developing resistance to them is an issue of great importance for pest control. The aim of this study was to investigate the sensitivity of synanthropic rodents in the Stara Zagora region, Bulgaria to some of the most significant first (warfarin and coumatetralyl) and second (bromadiolone and brodifacoum) generation anticoagulants. Resistance tests were carried out by a standard protocol using lethal feeding period tests and blood clotting response tests according to the European and Mediterranean Plant Protection Organization (Paris, France) standard. Studies were performed on 278 wild synanthropic rodents - 67 house mice (Mus musculus), 153 roof rats (Rattus rattus) and 58 brown rats (Rattus norvegicus). The rodents belonged to 11 populations inhabiting 9 animal farms in the region of Stara Zagora, Southern Bulgaria. High-level resistance to warfarinwas established in $100 \%$ of surveyed house mice and $92.1 \%$ of roof rats. Resistance to coumatetralyl was registered in $62.5 \%$ of the tested roof rats. Low-level resistance to bromadiolone was found in $38.5 \%$ of the surveyed roof rats and $23.1 \%$ of house mice. There was no resistance registered in brown rats. The sensitivity of all three rodent species to the strategic anticoagulant brodifacoum was high, and there were no signs of resistance. The results proved the resistance among synanthropic rodents and led to the conclusion that the resistance in house mice and roof rats to warfarin and coumatetralyl tends to be the main issue in pest control.
\end{abstract}

Key words: resistance, anticoagulant rodenticides, synantropic rodents

\section{INTRODUCTION}

Deratization is one of the main anti-epidemic measures, performed to reduce the economic damage from rodents and to keep the health and well-being of humans and animals $(1,2,3)$. Nowadays, the most widely used means of pest control are chemicals - so called rodenticides (4). In the recent decades, a serious change in the arsenal of rodenticide means has occured in Bulgaria. The use of acute

Corresponding author: Prof. Georgi Zhelev, $\mathrm{PhD}$

E-mail address: zhelev_vet@abv.bg

Present address: Department of Epidemiology, Infectious Diseases and Preventive Medicine, Faculty of Veterinary Medicine, Trakian University, Stara Zagora 6000, Bulgaria

Phone: $+35942699614,+359896976443$

Copyright: (C) 2019 Zhelev G.G. This is an open-access article published under the terms of the Creative Commons Attribution License which

permits unrestricted use, distribution, and reproduction in any medium, provided the original author and source are credited.

Competing Interests: The authors have declared that no competing interests exist.

Available Online First: 24 January 2019

Published on: 15 March 2019

https://doi.org/10.2478/macvetrev-2019-0010 rodenticides was terminated, mainly because of their high toxicity and the related environmental risks. Anticoagulant (AC) rodenticides gradually occupied their place and now they are the most widespread means of rodent control, both in Bulgaria and around the world $(4,5)$.

However, it is important to note that there is not a great variety of alternative non-anticoagulant rodenticides available for use (4). Therefore the issue of building a resistance to $\mathrm{AC}$ rodenticides is important for deratization. The resistance to $\mathrm{AC}$ rodenticides occurs in two main mechanisms: 1 . The occurrence of mutations in the gene encoding liver enzyme vitamin $\mathrm{K}$ epoxide reductase (VKOR); and 2. Accelerating the cytochrome P450 (CYP) systems which are responsible for metabolizing of the anticoagulant agents $(6,7)$.

The presence of resistant rodents leads to low efficiency of conducted deratization, increased economic costs and higher health risk for animals 
and humans $(8,9)$. Anticoagulant resistance in synantropic rodents is not a new biological phenomenon and has been known since 1958 (10). However, there is a increased development of the problem in recent years, resulting in the expansion of the geographical area of resistant populations, the rise of the number of affected rodent species and increase in the degree of the resistance (11, 12, 13).

This negative trend entailed the need to develop adequate measures for the control of resistant rodents globally. There are international organizations supporting scientific cooperation and exchange of information, while monitoring programs for resistance are implemented in many countries (14). However, in the Balkan Peninsula as a whole and in the Republic of Bulgaria, in particular, the information about the presence of anticoagulant resistance and its distribution among rodents is scarce and incomplete. This study aims to contribute to the elucidation of this problem by examining the sensitivity of wild synantropic rodents in animal facilities to some of the most frequently used anticoagulant rodenticides of the first and second generation.

\section{MATERIAL AND METHODS}

\section{Animals}

The tests were performed on wild synanthropic rodents caught in animal production facilities in the Stara Zagora region. The rodents were trapped by live traps in farms, where no anticoagulants were used during the last 6 months, according to EPPO recommendations (15). The rodents were weighed, sorted by sex and kept in individual cages under laboratory conditions. Before the test started, the animals passed through a quarantine and acclimatization period. During that period, the rodents were fed with pelleted feed and had permanent access to drinking water. The quarantine period was 14 days for the males and 25 days for the females. Thus, pregnancy was excluded. Only sexually mature adult animals were included in the experiments, assessed as clinically healthy, non-pregnant and showing normal feed intake. Two hundred and seventy-eight wild synanthropic rodents - 67 house mice (Mus musculus), 153 roof rats (Rattus rattus) and 58 brown rats (Rattus norvegicus) were tested for resistance to anticoagulants under laboratory conditions. Two

Table 1. Origin of experimental animals tested for resistance to anticoagulant rodenticides

\begin{tabular}{|c|c|c|c|c|}
\hline Site № & Facility & $\begin{array}{l}\text { Population № / } \\
\text { Rodent species }\end{array}$ & Test & $\underset{(n)}{\operatorname{Animals}}$ \\
\hline \multirow{4}{*}{1} & \multirow{4}{*}{$\begin{array}{l}\text { Stationary animal patient } \\
\text { facilities }\end{array}$} & \multirow{2}{*}{ 1/ Rattus rattus } & LFP & 14 \\
\hline & & & $\mathrm{BCR}$ & 19 \\
\hline & & \multirow{2}{*}{ 2/ Mus musculus } & LFP & 15 \\
\hline & & & BCR & 12 \\
\hline \multirow{3}{*}{2} & \multirow{3}{*}{ Pig farm } & 3/ Rattus rattus & LFP & 16 \\
\hline & & \multirow{2}{*}{ 4/ Mus musculus } & LFP & 11 \\
\hline & & & BCR & 14 \\
\hline 3 & Sheep farm & 5/Mus musculus & LFP & 15 \\
\hline 4 & Rabbit farm & 6/ Rattus rattus & LFP & 20 \\
\hline \multirow{2}{*}{5} & \multirow{2}{*}{ City zoo } & \multirow{2}{*}{ 7/ Rattus rattus } & LFP & 26 \\
\hline & & & BCR & 18 \\
\hline \multirow{2}{*}{6} & \multirow{2}{*}{ Dairy cattle farm } & \multirow{2}{*}{ 8/ Rattus norvegicus } & LFP & 13 \\
\hline & & & $\mathrm{BCR}$ & 15 \\
\hline \multirow{2}{*}{7} & \multirow{2}{*}{ Poultry farm } & \multirow{2}{*}{ 9/ Rattus norvegicus } & LFP & 12 \\
\hline & & & BCR & 18 \\
\hline 8 & Back yard (A) & 10/ Rattus rattus & $\mathrm{BCR}$ & 19 \\
\hline 9 & Back yard (B) & 11/ Rattus rattus & BCR & 21 \\
\hline
\end{tabular}

Legend: LFP - Lethal feeding period test; BCR - Blood clotting response test 
resistance tests were used - Lethal feeding period (LFP) test and Blood clotting response (BCR) test. One hundred and fifty-seven rodents were tested for warfarin resistance, 30 for coumatetralyl resistance, and 46 for brodifacoum resistance. The animals belonged to 11 populations inhabiting 9 animal production facilities - Table 1.

\section{Lethal feeding period tests for resistence to warfarin}

LFP-tests for resistence to warfarin were performed on 142 wild synantropic rodents - 25 brown rats, 76 roof rats and 41 house mice. LFPtests were conducted as per the standard protocol according to the European and Mediterranean Plant Protection Organization (EPPO) standard: PP 1/198(1) ,Testing rodents for resistance to anticoagulant rodenticides" (15). The test is based on feeding rodents a discriminating dose of an anticoagulant rodenticide, which causes death in $99 \%$ of susceptible rodents. Based on numerous research studies, EPPO has adopted and standardised methods for determination of discriminating doses of anticoagulant rodenticides in the different synanthropic rodent species (15). The warfarin baits were prepared using warfarin (analytical standard, Sigma-Aldrich, Germany) according to EPPO recommendations (15). The amount of consumed poisonous bait was determined on a daily basis.

After the treatment period, a 21-day monitoring period followed, during which the poisonous bait was replaced by nontoxic pelleted feed. The observation of experimental rodents was done twice daily and their health status was recorded. The animals that died during the treatment or monitoring period were necropsied in order to confirm the presence of haemorrhages. Only dead rodents with haemorrhages in the body were accepted to be warfarin-sensitive. Those who survived the 21-day monitoring period without any manifestations of haemorrhages, were accepted as resistant.

\section{Blood clotting response tests}

BCR-tests for AC resistence were performed on a total of 136 wild synantropic rodents - 33 brown rats, 77 roof rats and 26 house mice. The tests were carried out in accordance with EPPO standard (15). The BCR-test is based on the use of a discriminating dose of anticoagulant rodenticide, which causes a reduction in the percentage clotting activity below a certain arbitration level $(10 \%$ in the first generation
$\mathrm{AC}$ and $17 \%$ in the second generation $\mathrm{AC}$ ) in $99 \%$ of the susceptible rodents (15).

The test protocol included:

1) Determination of the prothrombin time before the administration of the anticoagulant rodenticide

The preparation of blood samples was performed on anesthetized (by inhalation of anesthesia with diethyl ether) rodents (16). They were obtained by using a glass capillary tubes from the eye venous sinus or by injection needles $(27 \mathrm{G})$ and syringes from the tail vein or the heart. The blood samples $(0,2 \mathrm{~mL})$ were mixed immediately with a solution of sodium citrate ( $31 \mathrm{mg} \mathrm{mL}^{-1}$, Sopharma, Bulgaria) in a ratio of $1: 9$ in plastic vials $(0.5 \mathrm{~mL})$, which were placed in an ice bath. In the laboratory, the samples were centrifuged in a refrigerated centrifuge $\left(2^{\circ} \mathrm{C}\right)$ at 1,500 $\mathrm{g} \mathrm{min}^{-1}$ for $15 \mathrm{~min}$, then the blood plasma was separated by pipetting (17).

For the determination of the prothrombin time, a thromboplastin reagent „Hemostat ThromboplastinSI" (Human, Germany) and a semi-automatic coagulometer „Ral Clot Sp 21 092“ (RAL, Spain) were used.

2) Oral administration of a discriminating dose of anticoagulant

The administration of discriminating doses of anticoagulant rodenticides was done orally on anesthetized (by inhalation of anesthesia with diethyl ether) experimental animals by a metal stomach tube.

Warfarin (100\% analytical standard, SigmaAldrich, Germany), coumatetralyl (99,9\% analytical standard, Sigma-Aldrich, Germany), liquid stock solutions with $0.25 \%$ bromadiolone (PelGar, UK) and $0.25 \%$ brodifacoum (Agrochem, Spain) were used for preparing the rodenticide solutions.

It has been found that certain warfarin resistant brown rats have a growing need for vit. $\mathrm{K}$ in the diet and can die due to dietary deficiency of this vitamin (15). This problem can be overcome by adding additional vit. $\mathrm{K}_{3}$ with no impact on the resistance tests. For this purpose and in accordance with the recommendations of EPPO (15), the drinking water for the brown rats was enriched in advance with Menadione sodium bisulphate (Sigma-Aldrich, Germany).

3) Determination of the prothrombin time after the administration of the anticoagulant and conversion to a percentage clotting activity

Blood samples were obtained 24 hours after the administration of first generation AC (warfarin, coumatetralyl) and 96 hours after the administration of second generation AC rodenticides (bromadiolone, brodifacoum) (15). The 
Table 2. Lethal feeding tests with warfarin in roof rats, brown rats and house mice

\begin{tabular}{|c|c|c|c|c|c|c|c|c|}
\hline \multirow{3}{*}{$\begin{array}{c}\text { Site } \\
\text { № }\end{array}$} & \multirow{2}{*}{\multicolumn{2}{|c|}{ Rodents }} & \multicolumn{2}{|c|}{ Sensitivity to warfarin } & \multirow{2}{*}{\multicolumn{2}{|c|}{$\begin{array}{c}\text { Daily intake of } \\
\text { warfarin }\left(\mathrm{mg} \mathrm{kg}^{-1}\right)^{*}\end{array}$}} & \multirow{2}{*}{\multicolumn{2}{|c|}{$\begin{array}{l}\text { Total intake of warfarin } \\
\qquad\left(\mathrm{mg} \mathrm{kg}^{-1}\right)^{*}\end{array}$}} \\
\hline & & & $\mathbf{S}$ & $\mathbf{R}$ & & & & \\
\hline & Spp. & n & $\begin{array}{c}\mathrm{n} / \% \\
(95 \% \mathrm{Cl})\end{array}$ & $\begin{array}{c}\mathrm{n} / \% \\
(95 \% \mathrm{Cl})\end{array}$ & $\mathbf{S}$ & $\mathbf{R}$ & $\mathbf{S}$ & $\mathbf{R}$ \\
\hline \multirow{2}{*}{1} & $\mathrm{RR}$ & 14 & $\begin{array}{c}0 / 0 \% \\
(0-25.2 \%)\end{array}$ & $\begin{array}{c}14^{\mathrm{a} 1 / 100 \%} \\
(74.9-100 \%)\end{array}$ & - & $\begin{array}{c}36.11^{\mathrm{a} 1 / \mathrm{a} 2, \mathrm{a}, \mathrm{a}, \mathrm{a}} \\
\pm 8.50\end{array}$ & - & $\begin{array}{c}1025.0^{\mathbf{a 1} / \mathbf{a} 2, \mathbf{a 3}, \mathbf{a} 4} \\
\pm 262.44\end{array}$ \\
\hline & MM & 15 & $\begin{array}{c}0 / 0 \% \\
(0-23.9 \%)\end{array}$ & $\begin{array}{c}15^{\mathrm{b} 1} / 100 \% \\
(76.1-100 \%)\end{array}$ & - & $\begin{array}{c}20.72^{\mathrm{b} 1 / \mathrm{b} 2} \\
\pm 4.67\end{array}$ & - & $\begin{array}{c}431.88^{\mathbf{b} 1 / \mathbf{b} 2} \\
\pm 96.71\end{array}$ \\
\hline \multirow{2}{*}{2} & $\mathrm{RR}$ & 16 & $\begin{array}{c}1 / 6.25 \% \\
(<0.01-30.3 \%)\end{array}$ & $\begin{array}{c}15^{\mathrm{a} 2} / 93.75 \% \\
(69.7-99.99 \%)\end{array}$ & $\begin{array}{l}15.62 \\
\pm 5.88\end{array}$ & $\begin{array}{c}12.15^{\mathrm{a} 2 / \mathrm{a} 1} \\
\pm 5.79\end{array}$ & 392.5 & $\begin{array}{c}341.25^{\mathrm{a} 2 / \mathrm{a} 1, \mathrm{a} 3, \mathrm{a} 4} \\
\pm 123.64\end{array}$ \\
\hline & MM & 11 & $0 / 0 \%$ & $\begin{array}{c}11^{\mathrm{b} 2} / 100 \% \\
(70.0-100 \%)\end{array}$ & - & $\begin{array}{c}11.45^{\mathbf{b} 2 / \mathbf{b} 1, \mathbf{b 3}} \\
\pm 2.91\end{array}$ & - & $\begin{array}{c}222.88^{\mathbf{b} 2 / 1 /, \mathbf{b 3}} \\
\pm 54.64\end{array}$ \\
\hline 3 & MM & 15 & $\begin{array}{c}0 / 0 \% \\
(0-22.7 \%)\end{array}$ & $\begin{array}{c}15^{\mathrm{b} 3} / 100 \% \\
(76.1-100 \%)\end{array}$ & - & $\begin{array}{l}21.45 \\
\pm 7.33\end{array}$ & - & $\begin{array}{c}430.63 \\
\pm 135.16\end{array}$ \\
\hline 4 & $\mathrm{RR}$ & 20 & $\begin{array}{c}1 / 5 \% \\
(<0.01-25.4 \%)\end{array}$ & $\begin{array}{c}19^{\mathrm{a} 3} / 95 \% \\
(74.6->99.9 \%)\end{array}$ & $\begin{array}{c}19.2 \\
\pm 7.41\end{array}$ & $\begin{array}{c}22.07^{\text {a3/a1 }} \\
\pm 3.11\end{array}$ & 546.0 & $\begin{array}{c}723.13^{\mathrm{a3} / \mathrm{a} 1, \mathrm{a} 2} \\
\pm 95.18\end{array}$ \\
\hline 5 & RR & 26 & $\begin{array}{c}4 / 15.38 \% \\
(5.5-24.2 \%)\end{array}$ & $\begin{array}{l}22^{\mathrm{a} 4} / 84.62 \% \\
(65.9-94.5 \%)\end{array}$ & $\begin{array}{l}16.41 \\
\pm 8.25\end{array}$ & $\begin{array}{c}26.55^{\mathrm{a} / \mathrm{a} 1} \\
\pm 9.75\end{array}$ & $\begin{array}{c}470.63 \\
\pm 174.41\end{array}$ & $\begin{array}{c}823.13^{\mathrm{a} 4 / \mathbf{a} 1, \mathrm{a} 2} \\
\pm 282.31\end{array}$ \\
\hline 6 & $\mathrm{RN}$ & 13 & $\begin{array}{c}13^{\mathrm{c} 1 / 100 \%} \\
(73.4-100 \%)\end{array}$ & $\begin{array}{c}0 / 0 \% \\
(0-26.6 \%)\end{array}$ & $\begin{array}{c}4.57 \\
\pm 1.02\end{array}$ & - & $\begin{array}{l}26.09 \\
\pm 5.77\end{array}$ & - \\
\hline 7 & $\mathrm{RN}$ & 12 & $\begin{array}{c}12^{\mathrm{c} 2} / 100 \% \\
(71.8-100 \%)\end{array}$ & $\begin{array}{c}0 / 0 \% \\
(0-28.2 \%)\end{array}$ & $\begin{array}{c}4.82 \\
\pm 1.32\end{array}$ & - & $\begin{array}{l}28.36 \\
\pm 7.58\end{array}$ & - \\
\hline
\end{tabular}

Legend: Spp. - rodent species; RR- roof rat (Rattus rattus); MM- house mouse (Mus musculus); RN- brown rat (Rattus

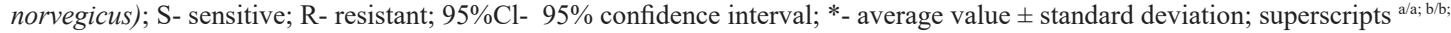
${ }^{\mathrm{c} / \mathrm{c}}$ indicate statistical significant differences between the groups concerned $(\mathrm{P}<0.05)$

conversion of prothrombin time from seconds to a percentage clotting activity (PCA) was performed according to prefabricated standard curves specific to each gender and rodent species. Standard curves were prepared in accordance with EPPO (15).

\section{4) Interpretation}

Rodents that possessed clotting activity of over $17 \%$ at 24 hours after administration of AC were considered resistant to warfarin and coumatetralyl, and sensitive - those with clotting activity of less than or equal to $17 \%$ (15). rodents with clotting activity over $10 \%$ at 96 -th hour after administration of $\mathrm{AC}$ were considered resistant to bromadiolone and brodifacoum, and sensitive those with clotting activity of less than or equal to $10 \%$ (15).

Assessing the level of resistance was carried out under the criteria established by Cowan et al. (18), by calculation of $\log _{10}$ percentage clotting activity after administration of $\mathrm{AC}$ rodenticide, on 24th or 96 th hour depending on the type of AC. The test animals were divided into three categories: 1) Sensitive individuals: $\log _{10}$ PCA < 1 ; 2) Resistant individuals with a low degree of resistance (technical resistance): $\log _{10} \mathrm{PCA}=1$ to 1.5 and 3) Resistant individuals with a high degree of resistance (resistance practical): $\log _{10}$ PCA $>1,5$.

The statistical data analyses were processed using GraphPad software. Values were expressed as a mean \pm standard deviation. The 95\% confidence interval of proportions were calculated by a modified Wald method. The statistical significance of the differences between the groups was determined by Tukey HSD post-hoc test.

\section{Ethics}

The experiments were conducted in strict compliance to regulations for humane treatment of experimental animals in the Republic of Bulgaria.

\section{RESULTS}

The results of lethal feeding tests and blood clotting response tests are presented in Tables 2 - 4 . 
Table 3. Blood clotting response tests with first generation anticoagulant rodenticides

\begin{tabular}{|c|c|c|c|c|c|c|c|c|c|}
\hline \multirow{3}{*}{ 望 } & \multirow{3}{*}{ 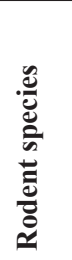 } & \multicolumn{4}{|c|}{$\begin{array}{c}\text { Sensitivity to warfarin } \\
\text { n/\% }(95 \% \mathrm{Cl})\end{array}$} & \multicolumn{4}{|c|}{$\begin{array}{c}\text { Sensitivity to coumatetralyl } \\
\text { n/\% }(95 \% \mathrm{Cl})\end{array}$} \\
\hline & & \multirow{2}{*}{ 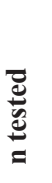 } & \multirow[b]{2}{*}{ Sensitive } & \multicolumn{2}{|c|}{ Resistant } & \multirow{2}{*}{ 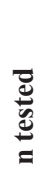 } & \multirow[b]{2}{*}{ Sensitive } & \multicolumn{2}{|c|}{ Resistant $\mathbf{n} / \%$} \\
\hline & & & & $\begin{array}{c}\text { Low } \\
\text { degree }\end{array}$ & High degree & & & $\begin{array}{c}\text { Low } \\
\text { degree }\end{array}$ & High degree \\
\hline 1 & $\mathrm{RR}$ & - & - & - & - & 6 & $\begin{array}{l}3 / 50 \% \\
(18.8- \\
81.2 \%)\end{array}$ & $\begin{array}{l}3 / 50 \% \\
(18.8- \\
81.2 \%)\end{array}$ & $\begin{array}{c}0 / 0 \% \\
(0-44.3 \%)\end{array}$ \\
\hline 5 & $\mathrm{RR}$ & - & - & - & - & 6 & $\begin{array}{l}2 / 33.33 \% \\
(9.3-70.4 \%)\end{array}$ & $\begin{array}{c}0 / 0 \% \\
(0-44.3 \%)\end{array}$ & $\begin{array}{c}4 / 66.67 \% \\
(29.6-90.8 \%)\end{array}$ \\
\hline 6 & $\mathrm{RN}$ & 9 & $\begin{array}{c}9 / 100 \% \\
(65.5-100 \%)\end{array}$ & $\begin{array}{c}0 / 0 \% \\
(0-34.5 \%)\end{array}$ & $\begin{array}{c}0 / 0 \% \\
(0-34.5 \%)\end{array}$ & 6 & $\begin{array}{c}6 / 100 \% \\
(55.7-100 \%)\end{array}$ & $\begin{array}{c}0 / 0 \% \\
(0-44.3 \%)\end{array}$ & $\begin{array}{c}0 / 0 \% \\
(0-44.3 \%)\end{array}$ \\
\hline 7 & $\mathrm{RN}$ & 6 & $\begin{array}{c}6 / 100 \% \\
(55.7-100 \%)\end{array}$ & $\begin{array}{c}0 / 0 \% \\
(0-44.3 \%)\end{array}$ & $\begin{array}{c}0 / 0 \% \\
(0-44.3 \%)\end{array}$ & - & - & - & - \\
\hline 8 & $\mathrm{RR}$ & - & - & - & - & 6 & $\begin{array}{l}1 / 16.67 \% \\
(1.1-58.2 \%)\end{array}$ & $\begin{array}{l}1 / 16.67 \% \\
(1.1-58.2 \%)\end{array}$ & $\begin{array}{c}4 / 66.67 \% \\
(29.6-90.8 \%)\end{array}$ \\
\hline 9 & RR & - & - & - & - & 6 & $\begin{array}{l}3 / 50 \% \\
(18.8- \\
81.2 \%)\end{array}$ & $\begin{array}{l}2 / 33.33 \% \\
(9.3-70.4 \%)\end{array}$ & $\begin{array}{c}1 / 16.67 \% \\
(1.1-58.2 \%)\end{array}$ \\
\hline
\end{tabular}

Legend: RR- roof rat (Rattus rattus); RN- brown rat (Rattus norvegicus); 95\%Cl- 95\% confidence interval

Table 4. Blood clotting response tests with second generation anticoagulant rodenticides

\begin{tabular}{|c|c|c|c|c|c|c|c|c|c|}
\hline \multirow{3}{*}{ 竞 } & \multirow{3}{*}{ 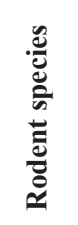 } & \multicolumn{4}{|c|}{$\begin{array}{c}\text { Sensitivity to bromadiolone } \\
\text { n/\% }(95 \% \mathrm{Cl})\end{array}$} & \multicolumn{4}{|c|}{$\begin{array}{c}\text { Sensitivity to brodifacoum } \\
\text { n/\% }(95 \% \mathrm{Cl})\end{array}$} \\
\hline & & \multirow{2}{*}{ 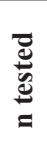 } & \multirow[b]{2}{*}{ Sensitive } & \multicolumn{2}{|c|}{ Resistant } & \multirow{2}{*}{ 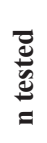 } & \multirow{2}{*}{ Sensitive } & \multicolumn{2}{|c|}{ Resistant } \\
\hline & & & & $\begin{array}{c}\text { Low } \\
\text { degree }\end{array}$ & High degree & & & $\begin{array}{c}\text { Low } \\
\text { degree }\end{array}$ & $\begin{array}{c}\text { High } \\
\text { degree }\end{array}$ \\
\hline \multirow{2}{*}{1} & $\mathrm{RR}$ & 7 & $\begin{array}{c}5 / 71.43 \% \\
(35.2- \\
92.4 \%)\end{array}$ & $\begin{array}{l}2 / 28.57 \% \\
(7.6-64.8 \%)\end{array}$ & $\begin{array}{c}0 / 0 \% \\
(0-40.4 \%)\end{array}$ & 6 & $\begin{array}{c}6 / 100 \% \\
(55.7-100 \%)\end{array}$ & $\begin{array}{c}0 / 0 \% \\
(0-44.3 \%)\end{array}$ & $\begin{array}{c}0 / 0 \% \\
(0-44.3 \%)\end{array}$ \\
\hline & MM & 6 & $\begin{array}{c}/ 83.33 \% \\
(41.8- \\
98.9 \%) \\
\end{array}$ & $\begin{array}{c}1 / 16.67 \% \\
(1.1-58.2 \%)\end{array}$ & $\begin{array}{c}0 / 0 \% \\
(0-44.3 \%)\end{array}$ & 6 & $\begin{array}{c}6 / 100 \% \\
(55.7-100 \%)\end{array}$ & $\begin{array}{c}0 / 0 \% \\
(0-44.3 \%)\end{array}$ & $\begin{array}{c}0 / 0 \% \\
(0-44.3 \%)\end{array}$ \\
\hline 2 & MM & 7 & $\begin{array}{c}5 / 71.43 \% \\
(35.2- \\
92.4 \%) \\
\end{array}$ & $\begin{array}{c}2 / 28.57 \% \\
(7.6-64.8 \%)\end{array}$ & $\begin{array}{c}0 / 0 \% \\
(0-40.4 \%)\end{array}$ & 7 & $\begin{array}{c}7 / 100 \% \\
(59.6-100 \%)\end{array}$ & $\begin{array}{c}0 / 0 \% \\
(0-40.4 \%)\end{array}$ & $\begin{array}{c}0 / 0 \% \\
(0-40.4 \%)\end{array}$ \\
\hline 5 & $\mathrm{RR}$ & 6 & $\begin{array}{c}4 / 66.67 \\
(29.6- \\
90.8 \%) \\
\end{array}$ & $\begin{array}{l}2 / 33.33 \% \\
(9.3-70.4 \%)\end{array}$ & $\begin{array}{c}0 / 0 \% \\
(0-44.3 \%)\end{array}$ & 6 & $\begin{array}{c}6 / 100 \% \\
(55.7-100 \%)\end{array}$ & $\begin{array}{c}0 / 0 \% \\
(0-44.3 \%)\end{array}$ & $\begin{array}{c}0 / 0 \% \\
(0-44.3 \%)\end{array}$ \\
\hline 7 & $\mathrm{RN}$ & 6 & $\begin{array}{c}6 / 100 \% \\
(55.7-100 \%)\end{array}$ & $\begin{array}{c}0 / 0 \% \\
(0-44.3 \%)\end{array}$ & $\begin{array}{c}0 / 0 \% \\
(0-44.3 \%)\end{array}$ & 6 & $\begin{array}{c}6 / 100 \% \\
(55.7-100 \%)\end{array}$ & $\begin{array}{c}0 / 0 \% \\
(0-44.3 \%)\end{array}$ & $\begin{array}{c}0 / 0 \% \\
(0-44.3 \%)\end{array}$ \\
\hline 8 & $\mathrm{RR}$ & 6 & $\begin{array}{c}1 / 16.67 \% \\
(1.1-58.2 \%)\end{array}$ & $\begin{array}{c}4 / 66.67 \% \\
(29.6-90.8 \%)\end{array}$ & $\begin{array}{c}1 / 16.67 \% \\
(1.1-58.2 \%)\end{array}$ & 7 & $\begin{array}{c}7 / 100 \% \\
(59.6-100 \%)\end{array}$ & $\begin{array}{c}0 / 0 \% \\
(0-40.4 \%)\end{array}$ & $\begin{array}{c}0 / 0 \% \\
(0-40.4 \%)\end{array}$ \\
\hline 9 & $\mathrm{RR}$ & 7 & $\begin{array}{c}6 / 85.71 \% \\
(46.7- \\
99.5 \%)\end{array}$ & $\begin{array}{c}1 / 14.29 \% \\
(0.5-53.4 \%)\end{array}$ & $\begin{array}{c}0 / 0 \% \\
(0-40.4 \%)\end{array}$ & 8 & $\begin{array}{c}8 / 100 \% \\
(62.8-100 \%)\end{array}$ & $\begin{array}{c}0 / 0 \% \\
(0-37.2 \%)\end{array}$ & $\begin{array}{c}0 / 0 \% \\
(0-37.2 \%)\end{array}$ \\
\hline
\end{tabular}

Legend: RR- roof rat (Rattus rattus); MM- house mouse (Mus musculus); $\mathrm{RN}-$ brown rat (Rattus norvegicus); 95\%Cl- 95\% confidence interval 


\section{Resistance to warfarin}

The existence of resistance to warfarin was found in all of the studied populations of roof rats and house mice, but not in the brown rats. One hundred and eleven of 142 rodents (78.17\%) tested by LPF-tests, were identified as resistant to warfarin. The highest percentage of resistance to warfarin was observed in house mice, where $100 \%$ of the tested individuals were determined as resistant. A high percentage of resistance in roof rats was also established in the following locations: $100 \%$ in the stationary for sick animals, $95 \%$ in the rabbit farm, $93.75 \%$ in the pig farm and $84.62 \%$ in the city zoo. All of the tested brown rats were sensitive to warfarin.

The results of the BCR-tests for resistance to warfarin performed with brown rats, confirmed the sensitivity of this species to warfarin. No resistant individuals were found there.

\section{Resistance to coumatetralyl}

Resistance to coumatetralyl was not detected in the studied brown rats. In contrast, $62.5 \%$ of the tested roof rats were determined as coumatetralylresistant. In stationary animal patient facilities and the backyard farm (B) a low level $\left(\log _{10}\right.$ PCA $=1$ to 1.5) was detected, while in the backyard farm (A) and the city zoo a high level of resistance to coumatetralyl $\left(\log _{10}\right.$ PCA $\left.>1.5\right)$.

House mice were not tested for resistance to coumatetralyl due to a lack of certain discriminating dose.

\section{Resistance to bromadiolone}

The results of the BCR-tests for resistance to bromadiolone showed that this problem did not occur in brown rats. All of the brown rats demonstrated a very high sensitivity to this $\mathrm{AC}$ rodenticide.

In contrast, bromadiolone-resistant individuals were detected in all the facilities, inhabited by roof rats and house mice. Almost all of them showed low grade resistance $\left(\log _{10} \mathrm{PCA}=1\right.$ to 1.5$)$. The most widespread resistance to bromadiolone was found in the roof rats from site №8 (backyard farm A), where the proportion of resistant individuals was $83.33 \%$ of the tested animals, while other sites populated with this species, showed a level of resistance between 14.29 and $33.33 \%$. The number of resistant house mice ranged between $16.67 \%$ in stationary animal patient facilities and $28.57 \%$ in the pig farm.

\section{Resistance to brodifacoum}

The results from the conducted BCR-tests showed a very high sensitivity to brodifacoum in all of the explored synantropic rodent species. One hundred percent of the tested rodents showed a very prolonged prothrombin time (over $600 \mathrm{sec}$ ) after administration of AC rodenticides. All individuals involved in the tests died by the 10th day after the anticoagulant administration. The clinical examination and pathological examination revealed signs of severe hemorrhagic diathesis - pale skin and visible mucous membranes, bleeding from the nose, vulva and anus, subcutaneous bleeding and rarely bleeding in the thoracic and the abdominal cavities. Similar signs were not observed in BCRtests with other AC rodenticides.

\section{DISCUSSION}

The methods for resistance detection are evolving and currently include: lethal feeding testing, blood clotting response testing, hepatic vitamin $\mathrm{K}$ epoxide reductase (VKOR) assessment and finding specific genotypes that are markers of resistance (19). There is no perfect method for testing resistance. All tests have their own advantages, but at the same time, they have significant disadvantages $(19,20)$. The first two are the most often used methods for resistance detection and estimation (20). They are also the most universal ones, because unlike the molecular-genetic and biochemical methods, they can find resistant individuals, regardless of the resistance mechanism. In our study, we used both of them because they are complementary and contribute to the main goal - finding the resistant individuals.

It is well known that warfarin is the first anticoagulant introduced in pest control more than 60 years ago and it is still used as a means of rodents control in some countries (2). It is one of the least toxic anticoagulant rodenticides (21). Therefore it is assumed that rodents which are sensitive to warfarin, are also sensitive to other anticoagulant rodenticides (22). Therefore, warfarin is an appropriate and sensitive marker for the initial detection of anticoagulant resistance.

The results of our LFP tests showed the highest prevalence $(100 \%)$ of resistance to warfarin in the house mouse. Pelz et al. (23) also established a high percentage of anticoagulant resistance among house mice in Europe. Similar results were previously established in the US by Ashton \& Jakson (24), 
which registered a high-level resistance to warfarin in $92 \%$ of the surveyed regions and over 46 percent prevalence of resistance among house mice. Not without a reason, the Rodenticide Resistance Action Group (25) warned that resistance of mice to anticoagulant rodenticides is so widespread nowadays, that sometimes it is difficult to find even one sensitive individual. The results of our studies strongly confirm this concern.

Our research also found high prevalence of warfarin resistance in roof rats. It ranged between $84.62 \%$ and $100 \%$ in the different sites. This result cannot be defined as surprising. Graves et al. (26), back in 1976 established widespread resistance to warfarin among populations of roof rats. They studied the resistance of 41 rodent populations, out of which $17(41.5 \%)$ were defined as resistant to warfarin. Of the 694 rats tested, 49.7\% were classified as resistant. Tanaka et al. (27) also reported a high percentage of warfarin resistance among roof rats in Japan. According to their studies, $80 \%$ of the wild rats in Tokyo are resistant.

It is known that the different species of synanthropic rodents have a different physiological sensitivity to the AC rodenticides. House mice possess higher natural, physiological tolerance to $\mathrm{AC}$, followed by roof rats $(1,2,3)$. We believe that this is one of the reasons for the widespread warfarin resistance in house mice and roof rats. This results in intake of higher doses of $\mathrm{AC}$ rodenticides for a prolonged period before the desired result occurs. Thus, in these species preconditions for more frequent and recurrent intake of sublethal doses of $\mathrm{AC}$ rodenticides are created, which is the basis for formation of resistance $(9,28)$.

When the LFP-tests wifh warfarin were conducted by Tanikawa et al. (29), it was found that the average intake dose of warfarin in resistant brown rats was $40,7 \mathrm{mg} \mathrm{kg}^{-1}$. In contrast, in our studies with roof rats and house mice we found much higher values in resistant individuals. In resistant roof rats, the average intake dose of warfarin was in the range of 341.25 to $1025 \mathrm{mg} \mathrm{kg}^{-1}$, and $222.88-$ $431.88 \mathrm{mg} \mathrm{kg}^{-1}$ in house mice. Similar to our results were obtained by other authors $(30,31)$, who found between 97 to $786 \mathrm{mg} \mathrm{kg}^{-1}$ intake dose of warfarin in resistant individuals. The results confirmed the higher resistance of these species in comparison with the brown rats.

The results of the BCR-tests correspond entirely with those obtained from the performed lethal food tests - anticoagulant resistance was proved in all of the populations of house mice and roof rats, but not in brown rats. The conducted BCR-tests showed the highest prevalence of anticoagulant resistance in roof rats $(32.5 \%)$, followed by house mice $(11.5 \%)$. The most widespread was the resistance to coumatetralyl detected in $50 \%$ of the studied individuals, followed by the resistance to bromadiolone $(28.88 \%$ ) and no resistance was found to brodifacoum. We believe that this is due to the differences in the toxicity of the anticoagulant agents. Studies of many researchers (32) show that there is a higher and more widely spread resistance to less toxic AC agents (warfarin, coumatetralyl), while with increasing toxicity of $\mathrm{AC}$, manifestations of resistance decreased. This tendency was strongly confirmed by our research.

It is known that brodifacoum is the most toxic anticoagulant, that is why many researchers define it as a strategic rodenticide in pest control and recommend its use to control AC resistant populations $(19,33,34)$. Our results entirely support this thesis - $100 \%$ of the studied rodents were sensitive to brodifacoum. Moreover - it was found in BCR-tests that the most high-grade bleeding disorders, the most severe post-mortem haemorrhagic events and mortality occured after administration of discriminating doses of brodifacoum. This fact confirms the high sensitivity of the studied rodents to brodifacoum, as well as its high toxicity.

It is believed that BCR-tests are more sensitive than LFP-tests and they can detect even the smallest deviations in the response of rodents $(19,35,36)$. Similarly to Baert et al. (37), we believe that one of the disadvantages of clotting tests is the greater difficulty in predicting the practical significance of resistance, i.e. to predict whether deratization with the corresponding $\mathrm{AC}$ will be successful or not in practice. Cowan et al. (18) offer a solution to this problem by calculating the logarithm of the PCA, which the rodents have after administration of anticoagulant agents. According to them, the resistance is low-level (technical) if $\log _{10}$ is in the range 1 to 1.5 and is high-grade (practical resistance) if it is above 1.5. According to them, the rodents of the second group would survive when performing field deratization.

According to our BCR-tests, the highest degree of resistance was found to coumatetralyl in roof rats from backyard farm (A) and the city zoo, where $66.67 \%$ of the tested rodents were found to have a high degree of resistance $\left(\log _{10}>1,5\right)$. It could be reasonably predicted that deratization with coumatetralyl baits would be unsatisfactory in these objects. Our research identified as the most serious and most widespread, the problem 
of the resistance to first generation anticoagulants (warfarin and coumatetralyl) in domestic mice and roof rats inhabiting animal farms in the region of Stara Zagora. Therefore, we do not recommend the use of these rodenticides to sites populated with these species of rodents. We recommend the use of brodifacoum-based rodenticide baits in farms populated with anticoagulant-resistant rodents.

The resistance testing we conducted, proved the presence of resistant synanthropic rodents in Bulgaria, which is not exceptional and unprecedented in world and European practices. Moreover - a survey performed by EPPO in 1992 found that signs of resistance to anticoagulant rodenticides were reported in $43 \%$ of the member states of EPPO. In fact, these are all the countries where tests for the presence of resistance among synantropic rodents were conducted (12).

\section{CONCLUSION}

The presence of anticoagulant resistance in synantropic rodents requires the introduction of continuous monitoring, allowing the correct choice of rodenticide means, consistent with the resistance status of the rodents. The resulting data should act as a basis for developing and implementing science-based strategies and measures for control of resistant rodents.

\section{CONFLICT OF INTEREST}

The authors declared that they have no potential conflict of interest with respect to the authorship and/or publication of this article.

\section{ACKNOWLEDGEMENTS}

The authors would like to express their gratitude to Prof. Slaveya Kesqkova from National Diagnostic Science-and-Research Veterinary Medical Institute, Sofia, Bulgaria for all advices and support.

\section{REFFERENCES}

1. Arsov, R., Yovchev, E., Girginov, G., Dimov, Iv. (1988). Epizootology. In: E. Yovchev (Ed.), Deratization, third part (pp. 289-309), Sofia: Zemizdat.
2. Tasheva, M., Kontev, Hr. (2000). Guide to controlling harmful rodents $(80 \mathrm{p}$.), Sofia: Videnov\&son.

3. Karadzhov, S., Ivanov, Y., Nedelchev, N., Kesiakova, S. (2004). Disinfection, disinsection and deratization in foot-and-mouth disease. In: S. Kesiakova (Ed.), Deratization (pp. 133-157), Sofia: Milena-print.

4. Michailova, A., Georgieva, Tz., Dimitrova N. (1998). List of disinfection, disinsection and deratization preparations authorized in the Republic of Bulgaria. In: Deratization preparations (pp. 181-189), Sofia: Videnov\&son.

5. Hadler, M., Buckle, Al. (1992). Forty five years of anticoagulant rodenticides - past, present and future trends. Proceeding of the 15th Vertebrate Pest Conference. March, 3-5, (pp. 149-155), Hyatt Newporter, Newport Beach, California, USA.

6. Ishizuka, M., Tanikawa, Ts., Tanaka, K.D., Heewon, M., Okajiama, F., Sakamoto, K.Q., Fujita, Sh. (2008). Pesticide resistance in wild mammals-Mechanisms of anticoagulant resistance in wild rodents. J. Toxicol. Sci. 33(3): 283-291.

https://doi.org/10.2131/jts.33.283

PMid:18670159

7. Andru, J., Cosson, J. F., Caliman, J. P., Benoit, E. (2013). Coumatetralyl resistance of Rattus tanezumi infesting oil palm plantations in Indonesia. Ecotoxicology 22, 377-386.

https://doi.org/10.1007/s10646-012-1032-y

PMid:23264020

8. Corrigan, R.M. (2001). Rodent control - a practical guide for pest management professionals. (353 pp.). Cleveland: GIE Media. PMCid:PMC1718769

9. Zhelev, G., Kesyakova, S1. (2012). Building resistance to anticoagulant rodenticides in deratization practice. Veterinary Collection (BG) 1 , 42-45.

10. Boyle, C.M. (1960). Case of apparent resistance of Rattus norvegicus Berkenhout to anticoagulant poisons. Nature 188, 517-525.

https://doi.org/10.1038/188517a0

11. Lund, M. (1984). Resistance to second-generation anticoagulant rodenticides. Proceeding of the 11th Vertebrate Pest Conference. March, 6-8, (pp. 89-94). Sacramento, California, USA.

12. Myllymäki, A. (1995). Anticoagulant resistance in Europe: appraisal of the data from the 1992 EPPO questionnaire. Pesticide Sci. 43, 69-72. https://doi.org/10.1002/ps.2780430111 
13. Pelz, H.-J. (2007). Spread of resistance to anticoagulant rodenticides in Germany. Int J of Pest Manage 53(4): 299-302.

https://doi.org/10.1080/09670870701245223

14. Rodenticide Resistance Action Committee (2016). RRAC guidelines on anticoagulant rodenticide resistance management (32 pp.). Brussels, Belgium. [cited 2017 October 19]

http:/www.rrac.info/content/uploads/RRAC_Guidelines_Resistance.pdf

15. OEPP/EPPO (1995). Efficacy evaluation of rodenticides: PP 1/198(1) „Testing rodents for resistance to anticoagulant rodenticides" (pp. 65-71). European and Mediterranean Plant Protection Organization, Paris, France.

16. Pelz, H.-J., Klemann, N. (2004). Rat control strategies in organic pig and poultry production with special reference to rodenticide resistance and feeding behavior. Wagening J Life Sci. 52(2): 173-184. https://doi.org/10.1016/S1573-5214(04)80012-5

17. Garcia-Manzano, A., Gonzalez-Llaven, J., Lemini, C., Rubio-Poo, C. (2001). Standardization of rat blood clotting tests with reagents used for humans. Proc. West. Pharmacol. Soc. 44, 153-155.

PMid:11793967

18. Cowan, D. P., Dunsford, G., Gill, J. E., Jones, A., Kerins, G. M., MacNicoll, A. D., Quy, R. J. (1995). The impact of resistance on the use of second-generation anticoagulants against rats on farms in southern England. Pestic. Sci. 43, 83-93. https://doi.org/10.1002/ps.2780430114

19. Bailey, C.I., Eason, C.T. (2000). Anticoagulant resistance in rodents. Conservation Advistory Science Notes 297, 1-8.

20. Bailey, C.I., Fisher, P., Eason, C.T. (2005). Assessing anticoagulant resistance in rats and coagulation effects in birds using small-volume blood samples. Science for conservation 249, 1-22.

21. Dubock A. C., Kaukeinen, D. E. (1978). Brodifacoum (Talon ${ }^{\circledR}$ rodenticide), a novel concept. Proceeding of the 8th Vertebrate Pest Conference. March, 7-9, (pp. 126-137). Red Lion Motor Inn Sacramento, California, USA.

22. MacNicoll, A.D., Kerins, G. M., Dennis, N. J., Gill, J. E. (1996). The distribution and significance of anticoagulant-resistant Norway rats (Rattus norvegicus) in England and Wales, 1988-1995. Proceeding of the 17th Vertebrate Pest Conference. March, 5-7, (pp. 179-185). Rohnert Park, California, USA.
23. Pelz, H.-J., Rost, S., Müller, E., Esther, A., Ulrich, R., Müller, C. (2012). Distribution and frequency of VKORC1 sequence variants conferring resistance to anticoagulants in Mus musculus. Pest Manag Sci. 68(2): 254-259.

https://doi.org/10.1002/ps.2254

PMid:21898757

24. Ashton, A.D., Jakson, W. B. (1982). Anticoagulant resistance in the house mouse in North America. Proceeding of a Conference on: 30 August-03 September (pp. 181-188). Hampshire, England.

25. Rodenticide Resistance Action Group (2012). RRAG house mouse resistance guideline. Rodenticide Resistance Action Group (11 pp.). Derby, UK. [cited 2017 October 19]

http://www.pestmagazine.co.uk/media/244094/rraghouse-mouse-resistance-guidelines-aug-2012.pdf

26. Graves, J.H., Rennison, B.D., Redfern, R. (1976). Resistance of ship rats Rattus rattus L. to warfarin. J Stored Prod Res. 12(2): 65-70. https://doi.org/10.1016/0022-474X(76)90025-4

27. Tanaka, K. D., Kawai, Y. K., Ikenaka, Y., Harunari, T., Tanikawa, T., Ando, S., et al. (2012). The genetic mechanisms of warfarin resistance in Rattus rattus found in the wild in Japan. Pestic Biochem Physiol. 103(2): 144-151.

https://doi.org/10.1016/j.pestbp.2012.04.011

28. Jackson, W. B., Ashton, A. D. (1986). Case histories of anticoagulant resistance. In: National Research Council (Ed.), Pesticide Resistance, In: National Academy Press (Ed.), Strategies and tactics for management (pp. 355-369). Washington, DC: National Academy Press.

29. Tanikawa, T., Harunari, T., Nagaoka, K. (2006). Warfarin-resistant brown rats, Rattus norvegicus, in Aomori Prefecture: the first case reported in Japan. Medical Entomology and Zoology 57(3): 241-244. https://doi.org/10.7601/mez.57.241

30. Negrin, O., Borroto, R., del.Solar, S. (1989). Negrin, O., Borroto, R., del Solar, S. (1989). Susceptibility of Mus musculus (Rodentia: Muridae) to warfarin. Science and Technology in Agriculture. Plant Protection (E) 12(3): 7-14. [in Spanish]

31. Endepols, S., Schuster, W. (1991). Laboratory investigations of resistance to warfarin of roof rats (Rattus rattus) in North East Germany. Zeitschrift Fuer Angewandte Zoologie 78(4): 489-495.

32. Berny, P. (2011). Challenges of anticoagulant rodenticides: resistance and ecotoxicology. Chapter 20. In: Margarita Stoytcheva (Ed.), Pesticides in a modern world- pest control and pesticides exposure and toxicity assessment (pp. 441-468). Croatia: InTech. https://doi.org/10.5772/19916 
33. Whisson, D. (1996). Rodenticides for control of norway rats, roof rats and house mice. Poultry fact sheet №23. Davis, California, USA: University of California.

34. Buckle, A. P., Klemann, N., Prescott, C. V. (2012). Brodifacoum is effective against Norway Rats (Rattus norvegicus) in a tyrosine139cysteine focus of anticoagulant resistance, Westphalia, Germany. Pest Manag. Sci. 68(12): 1579-1585.

https://doi.org/10.1002/ps.3352

PMid:23007948

35. Kerins, G., Langton, S.R., Mac Nicoll, A. (1993). The development of a blood clotting response test for discriminating between difenacoum resistant and susceptible Norway rats. Comp Biochem Physiol 104(1): 29-36.
36. Rodenticide Resistance Action Committee of CropLife International (2003). A reappraisal of blood clotting response tests for anticoagulant resistance and a proposal for standardized BCR test methods. CropLife International Technical Monograph (15 pp.). Brussels, Belgium. [cited 2017 October 19] http://www.rrac.info/content/uploads/technical_ monograph_2003_BCR.pdf

37. Baert, K., Stuyck, J., Breyne, P., Maes, D., Casaer, J. (2012). Distribution of anticoagulant resistance in the brown rat in Belgium. Belg. J. Zool. 142(1): 39-48. 